\title{
Implementasi Peraturan Daerah nomor 3 tahun 2011 tentang retribusi parkir di tempat khusus dalam pengelolaan parkir untuk meningkatkan pendapatan asli daerah
}

\author{
Alamsyah Richard Braksa *, Ridwan Ridwan \\ Program Studi Ilmu Pemerintahan Fakultas Ilmu Sosial dan Ilmu Politik, Universitas Muara Bungo \\ * Corresponding Author. E-Mail: alamsyahrichardumb@gmail.com
}

\begin{abstract}
Info Artikel
Abstrak

Histori Artikel:

Received: 9 Dec. 2019

Revision: 18 Dec. 2019

Accepted: 31 Dec. 2019

Kata Kunci:

implementasi; parkir dan

PAD; pendapatan asli

daerah; pengelolaan

parkir; Implementation;

Parking and PAD

Penelitian dilaksanakan di Dinas Perhubungan Kabupaten Merangin. Lokasi ini dipilih secara "purposive" yaitu dengan sengaja. Dengan pertimbangan bahwa Dinas Perhubungan merupakan lembaga yang diberi kewenangan dan tanggung jawab dari Pemerintah daerah Kabupaten Merangin dalam melakukan implimentasi perda No.3 Tahun 2011 tentang retribusi parkir di tempat khusus dalam pengelolaan parkir untuk meningkatkan pendapatan Asli Daerah (PAD). Penelitian ini dilakukan pada bulan Mei 2018 sampai Juni 2018. Penelitian ini bertujuan untuk untuk mengetahui implementasi Peraturan Daerah Kabupaten Merangin No. 3 tentang Retribusi Parkir di Tempat Khusus dan untuk mengetahui kendala-kendala Dinas Perhubungan dalam implementasi Peraturan Daerah tentang Retribusi Parkir di Tempat Khusus dalam pengelolaan parkir untuk meningkatkan pendapatan asli daerah Kabupaten Merangin. Untuk memperoleh data-data yang dibutuhkan dalam penelitian ini digunakan berbagai teknik yaitu Wawancara, Obsevasi dan Dokumentasi. Hasil penelitian menunjukkan bahwa proses implementasi Peraturan Daerah Kabupaten Merangin No. 3 tentang Retribusi Parkir di Tempat Khusus dalam pengelolaan parkir untuk meningkatkan Pendapatan Asli Daerah (PAD) pada umumnya sudah cukup efektif dilihat komunikasi, sumberdaya, disposisi dan struktur birokrasi. Adapun kendalakendala yang dihadapi Dinas Perhubungan dalam implementasi Peraturan Daerah tentang Retribusi Parkir di Tempat Khusus dalam pengelolaan parkir untuk meningkatkan pendapatan asli daerah Kabupaten Merangin adalah ketersediaan sarana dan prasarana parkir yang belum memadai dan sistem pengelolaan parkir yang belum efektif serta kurangnya kesadaran masyarakat terhadap perparkiran di tempat khusus.
\end{abstract}

The study was conducted at the Merangin District Transportation Agency. This location was chosen purposively. Considering that the Department of Transportation is an institution that is given the authority and responsibility of the Merangin Regency Regional Government in implementing the Regulation No. 3 of 2011 concerning parking fees in a special place in parking management to increase Regional Original Revenue (PAD). This research was conducted in May 2018 until June 2018. This study aims to determine the implementation of the Merangin District Regulation No. 3 concerning Parking Levies in Special Places and to find out the obstacles of the Department of Transportation in implementing Local Regulations on Parking Levies in Special Places in parking management to increase the original revenue of Merangin Regency. To obtain the data needed in this study, various techniques are used, namely Interview, Observation and Documentation. The results of the research show that the process of implementing the Merangin District Regulation No. 3 concerning Parking Levy in Special Places in parking management to increase Local Revenue (PAD) in general is quite effective in terms of communication, resources, disposition and bureaucratic structure. The obstacles faced by the Department of Transportation in the implementation of Regional Regulations on Parking Levies in Special Places in parking management to increase the original income of the Merangin Regency are the availability of inadequate parking facilities and infrastructure and parking management systems that have not been effective and the lack of public awareness of parking in a special place.

This work is licensed under a Creative Commons Attribution-ShareAlike 4.0 International License. 
Jurnal Politik dan Pemerintah Daerah, 1 (2), 2019 - 132

Alamsyah Richard Braksa, Ridwan Ridwan

\section{PENDAHULUAN}

Tingginya populasi penduduk yang dibarengi dengan kebutuhan mobilitas masyarakat perkotaan yang semakin tinggi berimplikasi pada peningkatan arus transportasi baik kendaraan pribadi maupun kendaraan umum. Selain masalah kemacetan yang kerap menjadi topik pembahasan, masalah parkir juga menjadi persoalan sendiri yang dialami oleh kota-kota besar di dunia. Pusat aktivitas kota pada umumnya mempunyai beberapa tipe penggunaan lahan. Pusat aktivitas dapat berupa sebuah pusat bisnis kota, sebuah kompleks universitas, kawasan industri dan pusat hiburan. Tingginya intensitas aktivitas di kawasan pusat kota memberikan pengaruh terhadap kondisi lalu lintas kendaraan dari wilayah-wilayah sekitarnya.

Alat transportasi merupakan alat yang vital untuk zaman modern seperti sekarang ini, sehingga banyaknya pengguna kendaraan pribadi terus bertambah dari tahun ke tahun, dikarenakan sifat konsumtif manusia. Apabila kendaraan terus bertambah, maka secara otomastis kebutuhan lahan parkir pun akan cenderung terus bertambah. Seiring bertambahnya jumlah kendaraan, sehingga perlu suatu perencanaan lahan parkir yang efisien dan dapat mengatur lahan parkir agar dapat digunakan secara optimal namun tetap nyaman dalam mengatur posisi parkir. Kehidupan sehari-hari parkir adalah pemandangan yang khas di mata kita. Sering kita melihat kendaraan parkir di ruas-ruas jalan. Tidak jarang juga kita melihat orang yang memarkir kendaraan seenaknya sendiri dan mengganggu pengguna jalan yang lain, baik yang berkendara maupun mereka yang berjalan.

Tata letak kota yang baik juga didukung salah satunya dengan fasilitas parkir yang tepat dan memadai, serta SDM yang tepat guna dalam mengelola fasilitas parkir tersebut. Perparkiran menjadi fenomena yang sering dijumpai dalam sistem transportasi. Fenomena parkir tersebut terjadi hampir di seluruh daerah yang ada di Indonesia. Parkir dapat berupa parkir kendaraan bermotor dan kendaraan tidak bermotor. Keduanya dapat mengganggu keindahan kota apabila tidak dilakukan penataan dengan baik. Rahardjo dan Adisasmita dengan konsep traffic is a function of buildings, terdapat hubungan positif antara jumlah gedung dan kepadatan lalu lintas. Gedung dengan aktivitas yang tinggi biasanya merupakan pusat perdagangan dari suatu daerah yang letaknya di pusat kota. Munculnya aktivitas pada pusat perdagangan akan mengakibatkan adanya bangkitan perjalanan, dari bangkitan perjalanan akan menimbulkan bangkitan parkir di daerah atau kawasan perdagangan (Adisasmita, \& Adisasmita, 2011).

Kabupaten Merangin merupakan Kabupaten terluas di Provinsi Jambi, dalam mendukung jalannya roda pemerintahan, pusat pemerintahan Kabupaten Merangin berada di Kota Bangko. Sebagai bukti pelayanan Pemerintah Daerah Merangin dalam peningkatan pelayanan publik khususnya berkaitan dengan fasilitas parkir, pemerintahan daerah Merangin telah mengeluarkan Peraturan Daerah No 16 Tahun 2000 yang dirobah menjadi Peraturan Daerah No. 3 Tahun 2011 tentang retribusi parkir di tempat khusus. Peraturan daerah ini mengatur retribusi pelayanan parkir di tempat khusus parkir yang merupakan pungutan yang dikenakan terhadap pemakaian kendaraan yang memarkir kendaraannya di atas bangunan petak-petak parkir dijalan/kawasan parkir, gedung dan atau peralatan parkir. Selain untuk meningkatkan mutu dan jenis pelayanan kepada masyarakat, secara jelas dan rinci dinyatakan bahwa penetapan Peraturan Daerah ini agar dapat menjamin terlaksananya usaha pemerintah dalam meningkatkan Pendapatan Daerah (PAD) sehingga dengan kemampuan yang semakin meningkat akan memberi manfaat besar bagi pembiayaan pemerintah dan pembangunan daerah (Bupati Maringin, 2011).

Pendapatan Asli Daerah (PAD) dapat dijadikan sebagai salah satu indikator kemampuan keuangan daerah. Besarnya kontribusi penerimaan PAD terhadap Anggaran Pendapatan dan Belanja Daerah (APBD) mencerminkan kemampuan manajerial Pemerintah Daerah dalam mengelolah berbagai sumber penerimaan daerah, sekaligus mencerminkan potensi perekonomian daerah. Pendapatan asli daerah merupakan hal yang dikehendaki setiap daerah karena keuangan daerah adalah hak dan kewajiban. Hak merupakan hak daerah untuk mencari sumber pendapatan daerah yang berupa pungutan pajak daerah, retribusi daerah atau sumber penerimaan lain-lain yang sesuai dengan ketentuan perundang-undangan yang berlaku. Sedangkan kewajiban adalah kewajiban daerah untuk mengeluarkan uang dalam rangka melaksanakan semua urusan pemerintah di daerah.

Kabupaten Merangin dalam pelaksanaan peraturan daerah masih banyak terjadi beberapa masalah terutama dalam penerimaan Retribusi Parkir yang belum dikelola secara optimal. Retribusi 
Jurnal Politik dan Pemerintah Daerah, 1 (2), 2019 - 133

Alamsyah Richard Braksa, Ridwan Ridwan

parkir di tempat khusus sebagai salah satu sumber Pendapatan Asli Daerah (PAD) yang bersumber dari masyarakat, dimana implementasi pengelolaannya dilakukan oleh dinas Perhubungan Merangin.

Dalam implementasi peraturan daerah tentang retribusi parkir di tempat khusus di Kabupaten Merangin yang pertanggung jawabannya dikelola oleh Dinas Perhubungan Kabupaten Merangin seakan menjadi permasalahan yang tidak ada ujung pangkalnya. Mulai dari masalah penerimaan retribusi parkir yang masih banyak menemukan kendala dalam pengelolaannya. Dalam implementasi peraturan daerah tentang retibusi parkir di tempat khusus masih ditemukan praktik pemungutan retribusi yang tidak sesuai dengan ketentuan dan prosedur baik yang terdapat di dalam perda maupun petunjuk pelaksanaan dan sering disalahgunakan oleh oknum yang tidak bertanggungjawab yang menggunakan momen tersebut untuk meraup keuntungan. Pelanggaran yang ditemukan seperti tidak tersedianya rambu-rambu parkir, papan tarif parkir, maupun satuan ruang parkir di setiap titik parkir sebagai kawasan perparkiran. Permasalahan tersebut sedikit banyaknya tentu berdampak terhadap target yang ingin dicapai terhadap penerimaan PAD Kabupaten Merangin, hal ini tergambar dari tabel target dan realisasi penerimaan parkir di tempat khusus sebagaimana digambarkan pada Tabel 1.

Tabel 1. Target dan Realisasi Penerimaan Retribusi Parkir Di Tempat Khusus Kabupaten Merangin Tahun 2013 2016

\begin{tabular}{ccccc}
\hline No & Tahun & Target $(\mathrm{Rp})$ & Realisasi $(\mathrm{Rp})$ & Persentase $(\%)$ \\
\hline 1 & 2014 & 125.500 .000 & 112.912 .000 & 89,97 \\
2 & 2015 & 135.550 .000 & 122.912 .000 & 90,68 \\
3 & 2016 & 135.550 .000 & 115.960 .000 & 85,55 \\
4 & 2017 & 155.000 .000 & 125.026 .000 & 80,66 \\
\hline
\end{tabular}

Sumber: BKAD Kabupaten Merangin, 2017

Berdasarkan Tabel 1 terlihat bahwa target retribusi parkir dari tahun selama 4 tahun terakhir (2014-2017) tidak pernah tercapai dan realisasi retribusi parkir di tempat khusus yang tertinggi hanya mencapai 90,68 \% yaitu di tahun 2015. Tidak tercapainya retribusi parkir di tempat khusus sejak tahun 2014 sampai tahun 2017 ini diduga disebabkan oleh permasalahan-permasalahan seperti pemberian karcis yang belum maksimal, adanya lokasi parkir yang beralih fungsi, adanya petugas parkir liar di luar dan adanya oknum-oknum yang tidak bertanggung jawab dalam perparkiran. Hambatan yang dihadapi dalam implementasi peraturan daerah tentang parkir di tempat khusus ini memang sering terjadi. Berbagai faktor mampu mempengaruhi implementasi parkir ataupun masalah yang dihadapi dalam pengendalian pendapatan parkir diantaranya yaitu: Penolakan untuk membayar, pengumpulan pendapatan oleh petugas tidak resmi, penarikan tarif parkir yang lebih tinggi, juru parkir tidak menyetorkan hasil dan penggunaan karcis lebih dari satu kali (Abubakar, 1998). Hal ini mengindikasikan perlu adanya perbaikan dalam pengelolaan dan penyelenggaraan perparkiran dalam rangka meningkatkan kontribusi parkir terhadap PAD Kabupaten Merangin.

Berdasarkan berbagai fakta di atas menunjukkan bahwa terdapat kendala dalam implementasi peraturan daerah tentang retribusi parkir di tempat khusus sehingga belum terpenuhinya fungsi Negara dan Daerah dalam mengoptimalkan penerimaan Daerah dari Retribusi, meskipun pada dasarnya retribusi daerah merupakan salah satu bentuk peran serta masyarakat dalam penyelenggaraan otonomi daerah. Setiap retribusi atau pungutan akan menimbulkan suatu beban baik bagi konsumen dalam hal ini adalah mengguna layanan maupun produsen dalam hal ini adalah penyedia layanan. Oleh karena itu, dalam upaya meningkatkan retribusi perparkiran Kabupaten Merangin, pemerintah harus memperhatikan berbagai faktor internal maupun eksternal dalam pelaksaananya sehingga mampu meningkatkan kontribusi retribusi parkir terhadap PAD Kabupaten Merangin. Apabila implementasi peraturan daerah tentang retribusi parkir di tempat khusus di suatu kota terimplementasi dengan baik, bukan hanya akan memberikan kenyamanan bagi masyarakat saja akan tetapi, parkir dapat menjadi salah satu sumber pendapatan daerah yang potensial untuk meningkatkan pendapatan asli daerah.

Melihat permasalahan pengelolaan parkir yang begitu kompleks, dan betapa besarnya kontribusi dari retribusi parkir terhadap pendapatan asli daerah. Dinas Perhubungan Kabupaten Merangin yang bertugas untuk mengelola perparkiran, dan menjaga ketertiban bidang perhubungan tentu saja mempunyai strategi, dan langkah yang tepat untuk mencapai target yang telah ditentukan oleh pemerintahan daerah Kabupaten Merangin. Oleh karena itu dibutuhkan suatu kajian mengenai bagaimana implemetasi Peraturan Daerah Kabupaten Merangin No.3 tentang Retribusi Parkir di Tempat Khusus Untuk Meningkatkan Pendapatan Asli Daerah (PAD) Kabupaten Merangin. 
Jurnal Politik dan Pemerintah Daerah, 1 (2), 2019 - 134

Alamsyah Richard Braksa, Ridwan Ridwan

\section{METODE}

\section{Lokasi dan Waktu Penelitian}

Penelitian dilaksanakan di Dinas Perhubungan Kabupaten Merangin. Lokasi ini dipilih secara purposive yaitu dengan sengaja. Dengan pertimbangan bahwa Dinas Perhubungan merupakan lembaga yang diberi kewenangan dan tanggung jawab dari Pemerintah daerah Kabupaten Merangin dalam melakukan implimentasi perda No.3 Tahun 2011 tentang retribusi parkir di tempat khusus dalam pengelolaan parkir untuk meningkatkan pendapatan Asli Daerah (PAD). Penelitian ini dilakukan pada bulan Mei 2018 sampai Juni 2018.

\section{Metode Penelitian}

Dalam penelitian ini penulis menggunakan metode penelitian kualitatif. Penelitian kualitatif bertujuan untuk mengungkapkan informasi kualitatif sehingga lebih menekankan pada masalah proses dan makna dengan mendeskripsikan sesuatu masalah. Penelitian yang dilakukan bersifat Deskriptif yaitu untuk mengetahui atau menggambarkan kenyataan dari kejadian yang diteliti atau penelitian yang dilakukan terhadap variabel mandiri atau tunggal, yaitu tanpa membuat perbandingan atau menghubungkan dengan variabel lain (Sugiyono, 2009). Sehingga memudahkan penulis untuk mendapatkan data yang objektif dalam rangka mengetahui dan memahami strategi Pengelolaan parkir yang dilakukan Dinas Perhubungan Kabupaten Merangin.

Dengan pendekatan ini diharapakan mampu menjaring realita di lapangan dengan mengumpulkan data secara langsung di lapangan melalui wawancara dokumentasi dan obsevasi.

\section{Teknik Pengumpulan Data}

Untuk memperoleh data-data yang dibutuhkan dalam penelitian ini digunakan berbagai teknik sebagai berikut:

Wawancara

Wawancara adalah percakapan dan tanya jawab yang diarahkan untuk mencapai tujuan tertentu. Dilakukan guna memperoleh informasi dan keterangan dari informan (Sugiyono, 2005). Peneliti mengadakan tanya jawab dengan para informan untuk memperoleh data mengenai hal-hal yang ada kaitannya dengan masalah penelitian ini dalam hal melakukan wawancara digunakan pedoman pertanyaan yang disusun berdasarkan kepentingan masalah yang diteliti. Kelonggaran cara ini akan mampu mengorek kejujuran informan untuk memberikan informasi yang sebenarnya dalam menganalisa implementasi Perda Kabupaten Merangin No. 3 Tahun 2011 tentang retribusi parkir di tempat khusus dalam pengelolaan parkir untuk meningkatkan PAD Merangin.

Obsevasi

Observasi adalah pengamatan dan pencatatan dengan sistematik fenomena-fenomena yang diselidiki (Hadi, 2004). Observasi dilakukan dengan jalan formal maupun nonformal. Metode ini mampu mengarahkan peneliti untuk mendapatkan sebanyak mungkin pengetahuan yang berkaitan dengan masalah penelitian yaitu Perda Kabupaten Merangin No. 3 Tahun 2011 tentang retribusi parkir di tempat khusus dalam pengelolaan parkir untuk meningkatkan PAD Merangin. Implementasi tersebut terbentuk dengan sumber daya manusia, dan sarana dan prasarana yang dimiliki untuk meningkatkan PAD Kabupaten Merangin.

\section{Dokumentasi}

Dokumentasi adalah metode yang menggunakan data yang tersedia yang berupa data verbal maupun nonverbal. Misalnya data yang terdapat pada surat-surat, jurnal, laporan-laporan dan sebagainya untuk kelengkapan data penelitian (Koentjaraningrat, 2008).

\section{Teknik Pemilihan Informan}

Pada penelitian ini teknik penentuan informan yang digunakan adalah: Purposive Sampling. Purposive Sampling adalah teknik pengambilan sampel sumber data dengan pertimbangan tertentu (Sugiyono, 2009), pertimbangan dalam hal ini yakni orang-orang yang memiliki kriteria dan dianggap paling tahu tentang apa yang kita harapkan dalam penelitian, atau mungkin dia sebagai penguasa 
Jurnal Politik dan Pemerintah Daerah, 1 (2), 2019 - 135

Alamsyah Richard Braksa, Ridwan Ridwan

sehingga akan memudahkan penelitian menjelajahi objek penelitian. Dalam penelitian ini, peneliti menggunakan informan penelitian melalui key person. Adapun yang menjadi informan kunci (key person) dalam penelitian ini dapat dilihat pada Tabel 2.

Tabel 2. Informan Penelitian

\begin{tabular}{cll}
\hline No & \multicolumn{1}{c}{ Nama } & \multicolumn{1}{c}{ Jabatan } \\
\hline 1 & Eri Sandy, S.Pt., M. Si & Kepala Unit Pelayanan Teknik \\
2 & Pahrizal Ependi & Bendahara Penerimaan Retribusi \\
3 & Lukman & Koordinator Parkir \\
4 & Afriansyah & Juru Pungut \\
5 & Taufik & Juru Pungut \\
6 & Fauzi & Juru Pungut \\
7 & Andrian & Juru Pungut \\
8 & Alpiansyah & Juru Pungut \\
9 & Faldo & Juru Parkir \\
10 & Tugiono & Juru Parkir \\
11 & M. Rizki & Juru Parkir \\
12 & Edo Saputra & Juru Parkir \\
13 & Hendra & Masyarakat \\
14 & M. Yusuf & Masyarakat \\
\hline
\end{tabular}

Jenis-Jenis Data

Adapun jenis data yang akan digunakan dalam penelitian adalah data primer dan data sekunder.

Data Primer

Data Primer, yaitu data yang diperoleh langsung dari responden yang akan dianalisa dalam hasil penelitian nantinya melalui wawancara yang berkaitan dengan permasalahan yang diteliti tentang implementasi Perda Kabupaten Merangin No 3. Tentang Retribusi Parkir di Tempat Khusus dalam pengelolaan parkir.

Data sekunder

Data sekunder adalah data yang diperoleh atau dikumpulkan oleh orang yang melakukan penelitian dari sumber-sumber yang telah ada (Sugiyono, 2009). Sumber tertulis dapat di bagi atas sumber buku dan majalah ilmiah, sumber dari arsip, dokumen pribadi dan dokumen resmi, data ini biasanya dari perpustakaan atau laporan dari peneliti terdahulu. Data sekunder juga disebut dengan data tersedia. Untuk penelitian ini data di peroleh dari sumber tertulis, yaitu bersumber dari buku-buku atau literatur yang berkaitan dengan judul penelitian ini.

\section{HASIL DAN PEMBAHASAN}

Keberhasilan implentasi kebijakan akan ditentukan oleh banyaknya variabel atau faktor-faktor yang masing-masing variabel tersebut saling berhubungan satu sama lain. Dalam pandangan Edwards III yang dikutip dalam buku Subarsono implementasi kebijakan dipengaruhi oleh empat variable (Subarsono, 2012), yaitu: sosialisasi, sumber daya, disposisi dan struktur birokrasi. Komunikasi merupakan salah satu faktor yang sangat penting dan berpengaruh dalam terciptanya suatu efiensi kerja. Terwujudnya suatu komunikasi yang baik antara pemerintah dengan pemerintah maupun pemerintah dengan masyarakat akan mewujudkan adanya hubungan yang sinergis dan terhindar dari kesalahpahaman atau miss komunikasi sehingga tujuan yang telah dirumuskan dapat tercapai. Komunikasi dikonsepsikan sebagai proses penyampaian pesan dari seseorang kepada orang lain atau pemberian pesan dari sumber kepada penerima. Komunikasi dilihat sebagai proses linear yang menggambarkan adanya proses pemindahan sesuatu yang kongkret dari suatu tempat ketempat lain. Pesan-pesan dalam berkomunikasi dianggap sebagai suatu yang konkrit dan relatif bersifat tetap, sehingga ketika dipindahkan akan tetap dengan jumlah yang sama dan relatif bersifat tetap.

Terdapat tiga indikator yang dapat digunakan dalam mengkur keberhasilan variabel komunikasi. Edward III dalam Agustino (2006) mengemukakan tiga variabel tersebut yaitu: 
Jurnal Politik dan Pemerintah Daerah, 1 (2), 2019 - 136

Alamsyah Richard Braksa, Ridwan Ridwan

Transmisi

Penyaluran komunikasi yang baik akan dapat menghasilkan suatu implementasi yang baik pula. Seringkali terjadi masalah dalam penyaluran komunikasi yaitu adanya salah pengertian (miskomunikasi) yang disebabkan banyaknya tingkatan birokrasi yang harus dilalui dalam proses komunikasi, sehingga apa yang diharapkan terdirtorsi di tengah jalan.

Kejelasan

Komunikasi yang diterima oleh pelaksana kebijakan (street-levelbureaucrats) harus jelas dan tidak membingungkan atau tidak ambigu/mendua.

Konsistensi

Perintah yang diberikan dalam pelaksanaan suatu komunikasi harus konsisten dan jelas untuk ditetapkan atau dijalankan. Jika perintah yang diberikan sering berubah-ubah, maka dapat menimbulkan kebingungan bagi pelaksana di lapangan.

Komunikasi dalam kebijakan Peraturan Daerah Kabupaten Merangin No. 3 Tentang Retribusi Parkir Di Tempat Khusus diwujudkan dalam suatu penyampaian berupa informasi mengenai target yang ingin dicapai, kenapa target harus dicapai serta pengaturan penjaga parkir yang dilekuarkan melalui Surat Perintah Tugas (SPT) yang dikeluarkan oleh kepala dinas Perhubungan Kabupaten Merangin setiap satu bulan sekali. Hal ini senada yang disampaikan oleh Kepala Unit Pelayanan Teknik ketika diwawancara yaitu :

"sebelum melaksanakan tugasnya, juru pungut/petugas parkir wajib mengambil Surat Perintah Tugas (SPT) satu kali dalam sebulan yang dikeluarkan oleh Bapak Kadin Perhubungan, melalui pengambilan SPT tersebut kita bisa mengontrol jur pungut/petugas parkir yang betul-betul bekerja, sehingga yang efektif dalam bekerja atau mencapai target akan tetap ditempatkan di lokasi tersebut sedangkan petugas yang tidak mecapai target akan di tempatkan ke lokasi yang targetnya kurang taua tidak banyak ${ }^{1 \%}$.

Dari hasil wawancara di atas dapat dijelakan bahwa Surat Perintah Tugas yang dikeluarkan oleh Kepala Dinas Perhubungan Kabupaten Bungo bukan hanya untuk melaksanakan tugas tapi juga dipergunakan untuk berkomunikasi dan pengontrolan terhadap petugas parkir. Dengan adanya SPT yang harus diambil setiap bulannya maka tercipta komunikasi yang baik antara juru parkir dan atasan dan apabila komunikasi seperti ini dilakukan terus menerus maka target yang diharapkan oleh dinas Perhubungan Kabupaten Merangin dari parkir di tempat khusus ini dapat tercapai.

Selain itu mekanisme yang digunakan dalam komunikasi oleh dinas Perhubungan Kabupaten Merangin dalam rangka implementasi peraturan Daerah Kabupaten Merangin No. 3 Tentang Retribusi Parkir Di Tempat Khusus adalah melalui sosialliasi Sosialisasi disini adalah suatu penyampaian informasi melalui proses penyuluhan kepada juru parkir pada saat pembayaran setoran atau saat penarikan setoran oleh koordinator parkir setiap hari kerja. Sosialisasi dilakukan oleh koordinator parkir setiap hari hari kerja seperti hasil wawancara dengan juru parkir yaitu :

"sosialisasi dilaksanakan secara rutin setiap hari kerja, hal ini dilakukan agar kami para juru parkir tidak lagi susah payah menyetorkan hasil parkir ke kantor atau bendahara dan penyetoran yang dilakukan sesuai dengan tiket yang habis pada hari itu. Setelah tiket dihitung kemudian di tulis berapa besar storan dan disaat itulah terjadi komunikasi baik tentang kendala-kendala yang terjadi dilapangan". ${ }^{2}$

Berdasarkan hal tersebut maka sosialisasi ini tentu sudah terjadwal sesuai dengan program sehingga jika dilakukan terus menerus maka dengan sendiri komunikasi yang baik dapat dicapai dan dengan menjalin komunikasi yang baik dan perhatian yang baik dari atasan terhadap bawahan maka bawahan akan lebih efektif meningkatkan hasil hasil kerjanya. Sosialisasi seperti ini sangat penting adanya agar juru parkir tetap di lokasi kerja atau tempat parkir.

\footnotetext{
${ }^{1}$ Eri Sandy, Hasil Wawancara. Senin, 22 Mei 2018

${ }^{2}$ Afriansah, Hasil Wawancara. Senin 4 Juni 2018
} 
Jurnal Politik dan Pemerintah Daerah, 1 (2), 2019 - 137

Alamsyah Richard Braksa, Ridwan Ridwan

Menyangkut akan komunikasi dalam sosialisasi penting dilakukan namun tidaklah seefektif yang diduga karena koordinator parkir memungut 38 titik parkir khusus yang ada di Kabupaten Merangin sehingga koordinator parkir hanyalah sekedar memungut, mencatat tanpa menghitung karcis yang diberikan pada subjek parkir atau masyarakat yang menggunakan tempat khusus parkir. Seiring dengan hal tersebut sosialisasi ini belum berjalan dengan lancar dikarenakan kurangnya perhatian dan jumlah koordinator parkir yang sedikit dalam sosialisasi, sehingga ketidakmerataan penyampaian informasi kepada juru parkir, selain itu seringkali juru parkir enggan melayani koordinator parkir. Akibatnya permasalahan tersebut penyampaian informasi itu tidak berjalan dengan semestinya, masih banyak juru parkir yang hanya meminta retribusi tanpa memberikan karcis parkir yang didalamnya berisikan peraturan daerah No. 3 Tahun 2011 antara lain yaitu tentang tarif parkir yang berlaku sehingga kebanyakan masyarakat tidak tahun tarif parkir yang berlaku.

Sosialisasi tentang kebijakan retribusi parkir oleh Dinas Perhubungan Kabupaten Merangin juga dilakukan oleh petugas pada UPTD Perparkiran dan petugas pos-pos parkir, seperti dinyatakan oleh Kepala UPT Perparkiran dan petugas pada pos parkir yang sempat diwawancarai sebagai berikut:

"Sosialisasi retribusi parkir ditempat khusus (Perda No. 3 Tahun 2011) juga dilakukan oleh UPT Perparkiran yaitu dengan menempelkan fotocopy perda tersebut di papan informasi kantor UPT Perparkiran dan juga di pos-pos parkir meskipun hanya beberapa tempat parkir khusus saja. Kami juga seringkali memberikan penjelasan kepada masyarakat mengenai kebijakan parkir tersebut meskipun kebanyakan masyarakat mengelak karena terburu-buru". ${ }^{3}$

Komunikasi dan sosialisasi tentang kebijakan retribusi parkir oleh Dinas Perhubungan Kabupaten Merangin yang sudah menjadi tugasnya untuk menyampaikan baik kepada petugas maupun kepada masyarakat namun belum berjalan efektif meksipun juga sudah ada adanya koordinasi dan kerjasama yang baik dan efektif dengan SKPD lain yang terkait. Hal itu dikemukakan oleh Bendahara penerimaan parkir Dinas Perhubungan, seperti berikut ini:

"Sehubungan dengan implementasi kebijakan retribusi parkir (Perda No.3 Tahun 2011), kami melakukan komunikasi dan koordinasi dengan instansi/SKPD terkait terutama dengan Badan Pengelola Pajak Daerah dan retribusi (BPPdRD) yaitu melalui pertemuan rutin atau melalui rapat/pertemuan khusus yang membicarakan hal-hal yang terkait dengan PAD". ${ }^{4}$

Pernyataan para informan di atas secara keseluruhan menunjukkan bahwa komunikasi yang dilakukan oleh pihak Dinas Perhubungan Kabupaten Merangin selama ini dalam rangka implementasi kebijakan retribusi parkir nampaknya sudah disampaikan dengan cukup efektif namun kendala yang ada seperti sumber daya manusia pelaksana parkir yang masih kurang dan masyarakat sadar parkir yang masih sedikit sehingga apa yang diharapkan dapat menjadi kendala dalam kebijakan retribusi parkir tertutama dasar hukumnya (Perda No.3 Tahun 2011) meskipun sudah dikomunikasikan (disosialisasikan atau dipublikasikan) dengan baik dan efektif kepada masyarakat baik melalui melalui informasi yang dipampang di kantor Dinas atau di Pos-Pos Parkir maupun melalui penjelasan langsung yang diberikan oleh para pegawai/petugas di kantor Dinas atau di Pos-Pos Parkir.

\section{Sumber Daya Manusia}

Sumber daya merupakan sumber energi dalam pelaksanaan sebuah kebijakan, karena tanpa adanya sumber daya kebijakan tidak akan berjalan, sama halnya dengan kebijakan retribusi parkir di Kabupaten Merangin tidak akan berjalan atau terlaksana tanpa adanya sumber daya yang terdiri dari sumber daya manusia baik kualitas dan kuantitas, serta informasi.

Sumber daya Manusia adalah salah satu faktor pendukung yang mana sumber daya manusia merupakan motor penggerak dalam pelaksanaan suatu kegiatan khususnya dalam bidang pelaksanaan pemungutan retribusi daerah. Kualitas dikatakan memadai apabila tingkat pendidikan formal yang dimiliki personil cukup baik sehingga memiliki kecakapan atau kemampuan yang cukup tinggi untuk melaksanakan tugas-tugasnya.

Berkenaan dengan kemampuan sumberdaya manusia (pegawai) ini berikut pernyataan kepala Unit Pelayanan Teknis perparkiran Kabupaten Merangin :

\footnotetext{
${ }^{3}$ Eri Sandy, Hasil Wawancara. Senin, 22 Mei 2018

${ }^{4}$ Pahriza Ependi, Hasil Wawancara. Rabu 31 Mei 2018
} 
Jurnal Politik dan Pemerintah Daerah, 1 (2), 2019 - 138

Alamsyah Richard Braksa, Ridwan Ridwan

"saya rasa secara kuantitas pegawai/petugas yang disediakan untuk pelaksanaan kebijakan retribusi parkir sudah cukup memadai, karena selain PNS ada juga sejumlah tenaga kontrak dan petugas pemungut retribusi. Secara kualitas kemampuan pegawai (PNS) Dinas umumnya sudah cukup memadai dilihat dari tingkat pendidikan dan kompetensi para pegawai. Kemampuan SDM para tenaga kontrak juga umumnya cukup memadai untuk tugas di bidang perparkiran dan pemungut retribusi karena mereka diangkat sesuai dengan persyaratan tingkat pendidikan, dan juga diberikan pelatihan khusus sebelum bertugas". 5

Syarat berjalannya suatu organisasi adalah kepemilikan terhadap sumberdaya. Implementasi kebijakan tidak efektif apabila para implementor kekurangan sumberdaya yang penting untuk melaksanakan kebijakan. Pentingnya sumberdaya dalam implementasi kebijakan mendapat perhatian dari Edward III yang menyatakan "kurangnya sumberdaya akan berakibat ketidakefektifan pelaksanaan/ penerapan kebijakan". Sumberdaya yang dimaksud mencakup terutama adalah sumberdaya manusia dan sumberdaya finansial. Sumberdaya manusia berkenaan dengan kecukupan baik kuantitas maupun kualitas implementor/pelaksana kebijakan yang dapat melingkupi seluruh kelompok sasaran. Sedangkan sumberdaya finansial menyangkut ketersediaan atau kecukupan dana untuk sebuah kebijakan atau program (Edward III dalam Nugroho, 2009).

Dari hasil penelitian yang dilakukan peneliti, menunjukan bahwa tuntutan kualitas belum sepenuhnya memadai sehingga akan menghambat proses penyelenggaraan pemungutan retribusi daerah karena aparaturlah yang akan bersentuhan langsung dengan tugas yang akan dilaksanakannya, sehingga aparatur yang ada di dinas Perhubungan belum sesuai dengan yang diharapkan.

Sedangkan menurut koordinator parkir bependapat lain dengan apa yang dikemukanan kepala UPT perpakiran Terkait dengan permasalahan diatas informan koordinator parkir menjelaskan bahwa :

"masalah sumber daya manusia dalam hal implementasi kebijakan pengelolaan pelayanan parkir seharusnya memiliki kemampuan terserdiri namun pada kenyataanya aparatur pelaksana masih memiliki Sumber daya yang rendah, terlihat dari ketidak mampuan mereka mengimplementasikan kebijakan ini sampai sekarang masih banyak masyarakat yang belum begitu paham mengenai kebijakan pelayanan parkir tempat khusus. sehingga perlu adanya perhatian khusus juga seperti dengan memberikan diklat dan pelatihan mengenai pengelolaan pelayanan parkir tempat khusus ${ }^{6}$.

Dari penjelasan diatas dapat dipahami bahwa dalam pengimplementasian ini adalah kurangnnya pengetahuan aparat pelaksana mengenai perda pengelolaan pelayanan parkir tempat khusus sehingga mereka tidak dapat menjelaskan secara maksimal kepada petugas parkir dan masyarakat yang ada. Hal ini akan menjadi hambatan atau kendala tidak terealisasinya retribusi parkir dengan baik.

Kemampuan sumberdaya manusia secara kuantitas dilihat dari kecukupan jumlah pegawai untuk pelaksanaan kebijakan retribusi parkir terutama di lapangan; sedangkan kemampuan sumberdaya manausia secara kualitas dilihat dari tingkat pemahaman terhadap tugas pekerjaan dan keterampilan yang dimiliki yang berkenaan dengan pelaksanaan retribusi parkir tersebut. Selain kemampuan SDM maka kemampuan finansial juga penting untuk implementasi kebijakan. Sehubungan dengan implementasi kebijakan retribusi parkir oleh Dinas Perhubungan Kabupaten Merangin nampaknya tidak menjadi persoalan serius karena dinilai cukup memadai, seperti dinyatakan oleh Kepala Unit Perparkiran, sebagai berikut:

"Sesuai pengalaman saya sebagai kepala UPT Perparkiran, anggaran yang tersedia cukup memadai untuk membiayai kegiatan operasional termasuk untuk mencetak karcis dan juga untuk membayar honor tenaga kontrak yang ada. Sejauh ini anggaran yang ada dapat digunakan dengan efisien dan efektif dan maksimal"”

Penjelasan kedua informan diatas dapat dimaknai bahwa pentingnya sumber daya manusia dalam melaksanakan suatu kebijakan daerah apalagi dalam pelaksanaan pelayanan, membutuhkan kemampuan pelaksana dalam melaksanakan pelayanan dengan baik, sehingga dapat menciptakan indeks kepuasan masyarakat, karena jika masyarakat puas dengan pelayanan, maka retribusi daerah

\footnotetext{
${ }^{5}$ Eri Sandy, Hasil Wawancara. Senin, 22 Mei 2018

${ }^{6}$ Lukman. Hasil Wawancara. Rabu 30 Mei 2018

${ }^{7}$ Eri Sandy, Hasil Wawancara. Senin, 22 Mei 2018
} 
Jurnal Politik dan Pemerintah Daerah, 1 (2), 2019 - 139

Alamsyah Richard Braksa, Ridwan Ridwan

akan meningkat dengan sendirinya tanpa harus melakukan penagihan. Hal yang senada juga dikatakan oleh beberapa orang juru parkir yaitu :

"ya kalau berbicara pendidikan atau sumberdaya kami ini memang kebanyakan kami diterima di Dishub berdasarkan tingkat pendidikan yang atau sesuai dengan ijazah, kalau untuk lebih tinggi lagi sih mau saja kalau diberikan kesempatan atau di sekolahkan atau dibiayai, kalau masalah target kami rasa storannya tergantung lokasi. Kalau tempat yang ramai ya, targetnya naik trus". ${ }^{8}$

Menurut Edward III dalam Agustino (2006), sumberdaya merupakan hal penting dalam implementasi kebijakan yang baik. Sumber daya utama dalam implementasi kebijakan adalah staf atau pegawai (street-level bureaucrats). Kegagalan yang sering terjadi dalam implementasi kebijakan, salah-satunya disebabkan oleh staf/pegawai yang tidak cukup memadai, mencukupi, ataupun tidak kompeten dalam bidangnya. Penambahan jumlah staf dan implementor saja tidak cukup menyelesaikan persoalan implementasi kebijakan, tetapi diperlukan sebuah kecukupan staf dengan keahlian dan kemampuan yang diperlukan (kompeten dan kapabel) dalam mengimplementasikan kebijakan

\section{Struktur Birokrasi}

Birokrasi merupakan salah-satu institusi yang paling sering bahkan secara keseluruhan menjadi pelaksana kegiatan. Keberadaan birokrasi tidak hanya dalam struktur pemerintah, tetapi juga ada dalam organisasi-organisasi swasta, institusi pendidikan dan sebagainya. Bahkan dalam kasus-kasus tertentu birokrasi diciptakan hanya untuk menjalankan suatu kebijakan tertentu. Implementasi kebijakan yang bersifat kompleks menuntut adanya kerjasama banyak pihak. Ketika strukur birokrasi tidak kondusif terhadap implementasi suatu kebijakan, maka hal ini akan menyebabkan ketidakefektifan dan menghambat jalannya pelaksanaan kebijakan.

Berdasakan penjelasan tersebut, maka memahami struktur birokrasi merupakan faktor yang fundamental untuk mengkaji implementasi kebijakan publik. Struktur birokrasi menurut Edward III merupakan faktor penting ke empat dalam implementasi kebijakan publik. Struktur birokrasi ini mencakup dua aspek penting yaitu mekanisme atau standar prosedur pelaksanaan (standard operating procedur atau SOP), dan struktur organisasi atau pembagian kerja. Dikatakan oleh Edward III, bahwa "para pelaksana kebijakan mungkin telah mengetahui apa yang harus mereka lakukan, dan mereka memiliki sikap dan sumberdaya yang cukup untuk melaksanakan kebijakan, tetapi mereka mungkin akan terhambat dalam pelaksanaan kebijakan oleh struktur birokrasi yang menonjol, yaitu standar prosedur pelaksanaan (SOP) dan pembagian kerja"

Aspek pertama dari struktur birokrasi adalah standar prosedur pelaksanaan atau standard operating procedur (SOP) yang dicantumkan dalam guideline kebijakan/program. SOP yang baik mencantumkan kerangka kerja yang jelas, sistimatis, tidak berbelit dan mudah dipahami oleh siapapun karena akan menjadi acuan dalam bekerjanya implementor/pelaksana kebijakan. Berkenaan SOP implementasi kebijakan retribusi parker oleh Dinas Perhubungan Kabupaten Merangin, berikut pernyataan Kepala Unit:

"SOP tentang implementasi kebijakan retribusi parkir oleh Dinas Perhubungan Kabupaten Mernagin sudah ditetapkan secara baku melalui surat kepurusan kepala dinas, dan semua pegawai pelaksana wajib memahaminya dengan jelas dan melaksanakannya. SOP yang ada sangat sistimatis, jelas dan ringkas atau tidak berbelit sehingga sangat mudah dipahami oleh pegawai pelaksana dan petugas lapangan"”.

Ukuran dasar SOP atau prosedur kerja ini biasa digunakan untuk menanggulangi keadaankeadaan umum diberbagai sektor publik dan swasta. Dengan menggunakan SOP, para pelaksana dapat mengoptimalkan waktu yang tersedia dan dapat berfungsi untuk menyeragamkan tindakan-tindakan pejabat dalam organisasi yang kompleks dan tersebar luas, sehingga dapat menimbulkan feksibilitas yang besar dan kesamaan yang besar dalam penerapan peraturan. Dalam pelaksanaan tentang SOP ini salah seorang juru parkir menanggapi pelaksanaan SOP yang ada tentang perpakiran di Kabupaten Merangin menyatakan :

\footnotetext{
${ }^{8}$ Taufik, Fauzi dan Adria. Hasil Wawancara. Rabu 13 Juni 2018

${ }^{9}$ Eri Sandy. Hasil Wawancara. Senin 22 Mei 2018
} 
"kalau berbicara SOP saya kurang atau sama sekali tidak ngerti, yang saya tahu tentang pekerjaan saya adalah mengambil Surat Perintah Tugas setiap bulannya, menyetorkan hasil parkir saya setiap harinya kepada pemungut parkir berdasarkan karcis yang habis, terus berapa target yang harus saya penuhi tentu saja saya tahu"10

Berdasarkan hasil wawancara tersebut maka dapat dijelaskan bahwa kebanyakan juru parkir di Dishub Kabupaten Merangin belum tahu SOP yang ada sehingga hal ini tentu akan menjadi kendala dalam pencapaian target yang telah ditetapkan untuk meningkatkan PAD Merangin. Berdasakan hasil penelitian Edward III yang dirangkum oleh Winarno (2012) menjelaskan bahwa: "SOP sangat mungkin dapat menjadi kendala bagi implementasi kebijakan baru yang membutuhkan cara-cara kerja baru atau tipe-tipe personil baru untuk melaksanakan kebijakan-kebijakan. Dengan begitu, semakin besar kebijakan membutuhkan perubahan dalam cara-cara yang lazim dalam suatu organisasi, semakin besar pula probabilitas SOP menghambat implementasi". "Namun demikian, di samping menghambat implementasi kebijakan SOP juga mempunyai manfaat. Organisasi-organisasi dengan prosedurprosedur perencanaan yang luwes dan kontrol yang besar atas program yang bersifat feksibel mungkin lebih dapat menyesuaikan tanggung jawab yang baru daripada birokrasi-birokrasi tanpa mempunyai ciri-ciri seperti ini".

Sifat kedua dari struktur birokrasi yang berpengaruh dalam pelaksanaan kebijakan adalah fragmentasi. Edward III dalam Winarno (2012) menjelaskan bahwa "fragmentasi merupakan penyebaran tanggung jawab suatu kebijakan kepada beberapa badan yang berbeda sehingga memerlukan koordinasi”. Pada umumnya, semakin besar koordinasi yang diperlukan untuk melaksanakan kebijakan, semakin berkurang kemungkinan keberhasilan program atau kebijakan. Fragmentasi mengakibatkan pandangan-pandangan yang sempit dari banyak lembaga birokrasi. Hal ini akan menimbulkan konsekuensi pokok yang merugikan bagi keberhasilan implementasi kebijakan. Mengenai fragmentasi dalam struktur birokrasi kebijakan retribusi parkir (Perda No.3 Tahun 2011) sebagaimana dikemukan oleh Bendahara Parkir yang mengungkapakan :

"bahwa dalam retribusi parkir ini Dishub Merangin melibatkan koordinasi dengan instansi/SKPD terkait terutama dengan Dinas Pendapatan, Pengelolaan Keuangan dan Aset Daerah (DPDKAD) yaitu melalui pertemuan rutin atau melalui rapat/pertemuan khusus yang membicarakan hal-hal yang terkait dengan PAD namun dalam pelakasanaan perpakiran ini hanya melibatkan kepala UPT perparkiran, koordinator parkir, saya sendiri bendahara dan juru parkir sebagai pelaksanan". ${ }^{11}$

Berdasarkan hal tersebut diatas maka fragmetasi dalam kebijakan parkir di tempat khusus dalam pengelolaan parkir untuk meningkatkan pendapatan asli daerah (PAD) Kabupaten Merangin hanya melibatkan pegawai yang ada di Dinas Perhubungan sendiri sehingga dengan fragmentasi yang terjadi sedikit dengan fungsi-fungsi yang jelas sesuai dengan jabatan masing-masning sehingga dengan $\mathrm{hl}$ ini keefektifkan Perda Kabupaten Merangin No.3 Tahun 2011 dapat mencapai target yang sudah diprogram dan dapat meningkatkan pendapatan asli daerah (PAD) Merangin.

Menurut Winarno (2012), hambatan-hambatan yang terjadi dalam fregmentasi birokrasi berhubungan dengan implementasi kebijakan publik yaitu "Pertama, tidak ada otoritas yang kuat dalam implementasi kebijakan karena terpecahnya fungsi-fungsi tertentu ke dalam lembaga atau badan yang berbeda-beda. Di samping itu, masing-masing badan mempunyai yurisdiksi yang terbatas atas suatu bidang, maka tugas-tugas yang penting mungkin akan terlantarkan dalam berbagai agenda birokrasi yang menumpuk". "Kedua, pandangan yang sempit dari badan yang mungkin juga akan menghambat perubahan. Jika suatu badan mempunyai feksibilitas yang rendah dalam misi-misinya, maka badan itu akan berusaha mempertahankan esensinya dan besar kemumgkinan akan menentang kebijakankebijakan baru yang membutuhkan perubahan".

\section{Kendala-Kendala Yang Dihadapi Dinas Perhubungan Dalam Implementasi Peraturan Daerah Tentang Retribusi Parkir Di Tempat Khusus Dalam Pengelolaan Parkir Untuk Meningkatkan Pendapatan Asli Daerah Kabupaten Merangin}

Kurangnya Ketersediaan Sarana dan Prasarana Parkir

\footnotetext{
${ }^{10}$ Edo Saputra. Hasil Wawancara. Rabu 20 Juni 2018

${ }^{11}$ Pahriza Ependi, Hasil Wawancara. Rabu 31 Mei 2018
} 
Jurnal Politik dan Pemerintah Daerah, 1 (2), 2019 - 141

Alamsyah Richard Braksa, Ridwan Ridwan

Sarana dan Prasarana diyakini sangat berperan dalam meningkatkan penerimaan Pajak Daerah. Sarana dan Prasarana yang merupakan faktor penunjang yang sangat penting dalam mendukung kelancaran proses pelaksanaan pemungutan pajak daerah. Dalam hal ini sarana dan prasarana parkir yang berupa ketersediaan lahan parkir yang representatif.

Terkait dengan hal tersebut informan kepala pelaksanaan Teknik, menjelaskan bahwa :

"potensi parkir di Kabupaten sangat besar, tetapi belum bisa dimaksimalkan. Hal ini disebabkan oleh ketersediaan lahan parkir yang sangat sempit sehingga jarak antara parkir dan parkir lain sangat dekat dan adanaya tempat parkir yang sudah banyak dipakai untuk berjualan oleh pedagang kaki lima serta banyaknya jalan keluar masuk seperti halnya di kawasan Pasar Baru, sehingga hal ini sangat menggangu perparkiran yang dampaknya parkir tidak terkelola dengan baik dalam mengimplementasikan kebijakan pelayanan tempat khusus ini masih mendapat presepsi yang kurang baik dari masyarakat". ${ }^{12}$

Dari pernyataan informan diatas, dapat dipahami bahwa perlunya lahan parkir yang aman bagi masyarakat, karena dengan kenyamanan dan pelayanan yang baik dari petugas parkir dan pihak pemerintah, dapat menimbulkan presepsi yang baik dimata masyarakat sehingga memudahkan aparat pelaksana untuk menjelaskan kebijakan perda mengenai retribusi parkir kepada seluruh masyarakat. Lebih lanjut mengenai ketersediaan saranana dan prasarana parkir, salah satu informan dari masyarakat menjelaskan bahwa :

"Dalam pelayanan parkir ditempat khusus sebenarnya sudah baik namun rambu-rambu yang ada atau sarana dan prasaran kayanya tidak memadai seperti papan parkir yang kadang-kadang ada, kadang tidak ada. Terus papan atau slogan tentang berapa tarif parkir begitu juga tidak ada kejelasan". ${ }^{13}$

Berdasarkan wawancara tersebut jelas bahwa sarana dan prasarana parkir saat ini belum memadai sehingga masyarakat yang sadar parkir terpaksa harus parikir sembarang tempat. Berdasarkan paparan dan penjelasan informan diatas dapat dipahami bahwa keberhasilan atau kegagalan suatu implementasi kebijakan adalah tergantung kepada petugas pelaksana dan pengguna parkir itu sendiri, walaupun dengan lahan parkir yang sempit, semua tergantung petugas pelaksana dalam melayani pengguna parkir dengan baik, sehingga pengguna parkir akan dapat memahami dan merasa puas dengan pelayanan yang diberikan. Hal ini tentunya akan dapat meningkatkan retribusi parkir di Kabupaten Merangin.

Menurut Moenir (2010) bahwa pelayanan publik yang kurang memadai yang selama ini dilakukan oleh pemerintah salah satunya karena tidak tersedianya sarana pelayanan yang memadai. Akibatnya pekerjaan menjadi lamban, waktu banyak hilang dan penyelesaian masalah terlambat.

Kendala dalam pelayanan parkir tempat khusus juga disebabkan adanya miss oriented yang dilakukan oleh pihak Dinas Perhubungan Kabupaten Merangin. Adapun yang dimaksud miss oriented adalah penyelenggaraan pelayanan parkir tempat khusus belum mampu memenuhi tujuan dari penyelenggaraan parkir tempat khusus parkir secara keseluruhan. Capaian tujuan yang dicapai hanya secara finansial yaitu tujuan peningkatkan PAD, sedangkan dalam tujuan meningkatkan pelayanan parkir di tempat khusus, pihak penyelenggara layanan perlu untuk lebih berusaha dalam mewujudkan tujuan tersebut. Hal ini sesuai dengan hasil survei yang dilakukan oleh Yappika dalam Kurniawan dan Puspitosari (2007). buramnya pelayanan publik selama ini dipengaruhi oleh faktor manajemen dari pelaksanaan pelayanan publik. Selama ini pelaksanaan pelayanan publik lebih bersifat state oriented tidak public oriented. Di mana kepentingan negara lebih menjadi prioritas, segala yang menyangkut negara akan mendapatkan porsi yang lebih dibandingkan dengan kepentingan masyarakat (Kurniawan \& Puspitosari, 2007).

\section{Sistem Pengelolaan Parkir Belum Terkelola dengan Baik}

Dalam suatu implementasi kebijakan tentunya harus bisa mengelola kebijakan itu dengan baik. Demikian pula halnya dengan pengelolaan kebijakaan pelayanan parkir di tempat khusus di Kabupaten Merangin, untuk dapat mengelola parkir dengan baik perlunya pendataan lokasi parkir, dan penagihan

\footnotetext{
${ }^{12}$ Eri Sandy. Hasil Wawancara. Senin 22 Mei 2018

${ }^{13}$ Hendra. Hasil Wawancara. 25 Juni. 2018
} 
Jurnal Politik dan Pemerintah Daerah, 1 (2), 2019 - 142

Alamsyah Richard Braksa, Ridwan Ridwan

secara teratur serta konsisten oleh petugas parkir. Terkait dengan permasalahan diatas informan juru parkir lebih lanjut menjelaskan bahwa :

"sistem pengelolaan parkir tempat khsus parkir di Kabupaten Merangin memang belum terkelola dengan baik, karena adanya oknum masyarakat yang menggunakan lahan parkir tanpa sepengetahuan petugas sehingga mereka tidak akan menyetor hasil retribusi parkir yang mereka dapatkan. Hal ini sangat menghambat implementasi kebijakan yang akan diterapkan kepada masyarakat. Oleh karena itu pihak pemerintah khususnya yang mengelola parkir pemerintah lebih tegas dan mendata lahan parkir yang di telah digunakan oleh masyarakat secara ilegal". ${ }^{14}$

Senada dengan penjelasan informan Koordinator parkir juga menambahkan bahwa :

"dalam pengelolaan parkir tempat khusus ini pihak pemerintah selalu berusaha untuk memaksimalkan pengelolaan parkir, hanya saja masih banyak pintu keluar masuk (tidaksatu pintu) seperti di Pasar Baru serta petugas parkir yang belum memahami betul bagaimana tata cara mengelola kendaraan yang diparkir dengan baik sehingga pelayanan parkir ini dapat menggangu arus lalu lintas dipasar yang ada". ${ }^{15}$

Penjelasan kedua informan diatas dapat dipahami bahwa pengelolaan parkir di Kabupaten Merangin belum berjalan sesuai dengan harapan pemerintah, hal ini dapat dilihat dari indeks kepuasan masyarakat yang belum terpenuhi dengan kata lain pelayanan yang diberikan selama ini masih belum memenuhi harapan pelanggan atau masyarakat, dimana masih dirasakan kelemahan-kelemahan yang dampaknya sering merugikan masyarakat.

Terkait dengan masalah diatas seorang petugas parkir lain juga menjelaskan bahwa :

"pengelolaan parkir di tempat khusus, memang selalu ada masalah, bukan hanya petugas parkir yang tidak dapat menertibkan parkiran dengan baik tapi ada juga masyarakat lain yang belum tertib dengan memarkirkan kenderaan di luar tempat khusus yang telah disediakan, apalagi pengguna parkir roda empat yang membutuhkan lahan parkir sedikit luas, terkadang petugas juga terganggu dengan kondisi tersebut". ${ }^{16}$

Dari penjelasan informan diatas dapat dimaknai bahwa sistem pengelolaan pelayanan parkir ini dapat dikelola dengan baik jika ada kerja sama yang antara pihak pemerintah, petugas parkir dan masyarakat sebagai pengguna parkir, yaitu bagaimana upaya pemerintah untuk mensosialiasikan lebih jelas mengenai kebijakan pelayanan parkir di tempat khusus parkir ini kepada seluruh masyarakat agar ketika kebijakan ini di terapkan oleh petugas yang ada, masyarakat sudah memahami dan akan membayar retribusi parkir yang mereka gunakan.

Jika dilihat dari tarif parkir sebenarnya sudah terdapat dalam karcis yang sudah disediakan dan diberikan saat pemungutan parkir namun kendala lain seringnya karcis yang ada tidak diberikan kepada pengguna parkir hal ini juga dinyatakan oleh seorang informan dari masyarakat yang menyatakan :

"saya sebagai masyarakat juga tidak tahu karcis parkir apa warnanya dan berapa duitnya sekali parkir karena setiap kali saya parkir saya tidak ada menerima karcis dari juru parkir sehingga hal ini menjadi pertanyaan bagi saya"17.

Hal senada juga dikemukanan oleh koordinator parkir yang menyatakan bahwa :

"memang pada prinsipnya permasalahan lahan parkir ini adalah hal utama yang menjadi kendala dalam mengimplementasikan perda No. 03 Tahun 2011 mengenai retribusi pelayanan parkir di tempat khusus, apalagi melihat petugas parkir yang tidak mau menggunakan karcis parkir dalam pengelolaan parkir tersebut. Walaupun telah memberikan karcis kepada petugas parkir, mereka hanya akan menggunakan sebagian dari karcis tersebut. Sehingga pendapatan retribusi parkir yang akan mereka setor tidak sesuai dengan pendapatan yang sebenarnya". ${ }^{18}$

\footnotetext{
${ }^{14}$ Alfiansah. Hasil Wawancara. Kamis 14 Juni 2018

${ }^{15}$ Lukman. Hasil Wawancara. Rabu 30 Mei 2018

${ }^{16}$ Edo Saputra. Hasil Wawancara. Rabu 20 Juni 2018

${ }^{17}$ Hendra. Hasil Wawancara. 20 Juni 2018

${ }^{18}$ Lukman. Hasil Wawancara. Rabu 30 Mei 2018
} 
Jurnal Politik dan Pemerintah Daerah, 1 (2), 2019 - 143

Alamsyah Richard Braksa, Ridwan Ridwan

Berbicara mengenai tarif parkir yang berlaku sudah diatur dalam Peraturan Daerah (Perda) Mernagin yaitu berdasarkan Perda Kabupaten Merangin Nomor 3 Tahun 2011 yang tertera pada BAB VIII tentang struktur dan besarnya tarif parkir pasal 10 adalah sebagai berikut: (1) Atas jasa pelayanan Tempat Khusus Parkir, dikenakan retribusi; (2) Besarnya retribusi sebagaimana dimaksud pada ayat (1) untuk setiap kendaraan sekali parkir ditetapkan sebagai berikut: (a) Kendaraan bermotor roda dua sebesar Rp. 1000,- (Seribu Rupiah); (b) Kendaraan bermotor roda empat sebesar Rp. 2.000,- (Dua Ribu Rupiah); dan (c) Kendaraan bermotor roda enam sebesar Rp. 3.000,- (Tiga Ribu Rupiah)

\section{SIMPULAN}

Proses implementasi Peraturan Daerah Kabupaten Merangin No. 3 tentang Retribusi Parkir di Tempat Khusus dalam pengelolaan parkir untuk meningkatkan Pendapatan Asli Daerah (PAD) pada umumnya sudah cukup efektif dilihat dari empat aspek penting dari proses implementasi kebijakan sebagaimana yang dikemukakan oleh Edward III, yaitu: (a) komunikasi (disosialisasikan atau dipublikasikan) dengan baik dan efektif, (b) sumberdaya aparatur pelaksana masih memiliki secara kualitas memiliki kompetensi dan bertanggung jawab serta anggaran yang disediakan sudah tersedia dan mencukupi, (c) disposisi atau sikap pelaksana yang cenderung positif terhadap kebijakan dan (d) struktur birokrasi sesuai dengan SOP yang tetapkan dan koordinasi sudah melibatkan instansi yang terkait, sehingga implementasi kebijakan retribusi parkir telah menunjang cukup berarti terhadap peningkatan penerimaan PAD Kabupaten Merangin.

Adapun kendala-kendala yang dihadapi Dinas Perhubungan dalam implementasi Peraturan Daerah tentang Retribusi Parkir di Tempat Khusus dalam pengelolaan parkir untuk meningkatkan pendapatan asli daerah Kabupaten Merangin adalah : (a) ketersediaan sarana dan prasarana parkir yang belum memadai dan (b) sistem pengelolaan parkir yang belum efektif serta kurangnya kesadaran masyarakat terhadap perparkiran di tempat khusus.

Berdasarkan kesimpulan hasil penelitian tersebut dan beberapa penemuan dalam penelitian ini, maka perlu dikemukakan beberapa saran sebagai berikut: (1) Implementasi masih perlu ditingkatkan kearah yang lebih baik lagi, terutama sumber daya manusia pelaksana dan juga aspek lain seperti komunikasi, disposisi, struktur birokrasi; (2) Hasil penerimaan retribusi parkir yang sudah dicapai selama beberapa tahun terakhir ini masih dapat ditingkatkan, terutama untuk retribusi tempat khusus dalam hubungan itu hal yang perlu dilakukan ialah lebih mengefektifkan implementasi kebijakan yang sudah ada terutama melalui peningkatan kapasitas SDM petugas lapangan pada pos-pos parkir.

\section{DAFTAR PUSTAKA}

Abubakar, I. (1998). Pedoman perencanaan dan pengoperasian fasilitas parkir. Jakarta: Direktorat Bina Sistem lalu Lintas dan Angkutan Kota Direktorat Jenderal Perhubungan Darat.

Adisasmita, R., \& Adisasmita, S. A. (2011). Manajemen transportasi darat: mengatasi kemacetan lalu lintas di kota besar. Jakarta. Graha Ilmu.

Agustino, E. (2008). Dasar-dasar kebijakan publik. Bandung: Alfabeta.

Bupati Maringin. (2011). Peraturan Daerah Kabupaten Merangin No. 3 Tahun 2011 tentang retribusi parkir di tempat khusus

Hadi, S. (2004). Metodologi research. Yogyakarta: Andi.

Koentjaraningrat, K. (2008). Metode-metode penelitian masyarakat. Jakarta: Gramedia

Kurniawan, L. J., \& Puspitosari, H. (2007). Wajah buram pelayanan publik. Malang: In-TRANS Publishing.

Moenir, A. S. (2010). Manajemen pelayanan umum di Indonesia. Jakarta: Bumi Aksara.

Nugroho, R. (2009). Public Policy. Jakarta: PT. Elex Media Komputindo.

Subarsono, A. G. (2012). Analisis kebijakan publik: konsep, teori dan aplikasi. Yogyakarta: Pustaka Pelajar. 
Jurnal Politik dan Pemerintah Daerah, 1 (2), 2019 - 144

Alamsyah Richard Braksa, Ridwan Ridwan

Sugiyono, S. (2005). Metode penelitian administrasi. Bandung: Alfabeta.

Sugiyono, S. (2009). Metode penelitian kuantitatif dan kualitatif dan $R \& D$. Bandung: Alfabeta.

Winarno, B. (2012). Kebijakan publik: Teori, proses, dan studi kasus: edisi dan revisi terbaru. Yogyakarta: Center for Academic Publishing Service. 